\title{
生活環境における銀曝露とその健康影響
}

\author{
宮山 貴光 ${ }^{* 1}$, 荒井 裕太 ${ }^{* 2}$, 平野靖史郎 $* 1,2$ \\ *1 独立行政法人国立環境研究所 \\ *2 千葉大学大学院薬学研究院
}

\section{Environmental Exposure to Silver and its Health Effects}

\author{
Takamitsu MIYAYAMA*1, Yuta ARAI*2 and Seishiro HIRANO*1,2 \\ ${ }^{*}$ National Institute for Environmental Studies, Tsukuba, Ibaraki \\ ${ }^{*}$ Graduate School of Pharmaceutical Sciences, Chiba University, Chiba
}

\begin{abstract}
Silver (Ag) possesses a well-known antibacterial activity and has been used for medical treatment and cosmetics such as wound dressing and deodorant powders. Occupational Safety and Health Administration (OSHA) and Mine Safety and Health Administration (MSHA) proposed that the permissible exposure limit (PEL) for both metallic and most soluble Ag compounds should be $0.01 \mathrm{mg} / \mathrm{m}^{3}$. Argyria and argyrosis are known to be caused by deposition of insoluble $\mathrm{Ag}$ in the dermis and cornea/conjunctiva. However, the metabolic behavior and biological roles of $\mathrm{Ag}$ have not been well characterized in mammals. $\mathrm{Ag}$ can be absorbed into the systemic circulation from drinking water, and also through parenteral routes such as inhalation and dermal exposure. Experimental studies have demonstrated that $\mathbf{A g}^{+}$induces and binds to metallothionein I and II (MTs), which are cysteine-rich proteins, in cells. MTs are major cytoplasmic metal binding proteins and thereby reduce cellular damage caused by toxic heavy metals including Ag. Profiles of Ag distribution in MTs and other Ag-binding proteins can be determined using high performance liquid chromatography-inductively coupled plasma mass spectrometry (HPLC-ICP-MS). This technique directly provides information on the intracellular behavior of $\mathrm{Ag}$, which is important for elucidating the mechanism underlying Ag toxicity. Silver nanoparticles (AgNPs) are also commercially used mainly as antimicrobial agents. Despite the widespread use of AgNPs, relatively few studies have been undertaken to evaluate the health effects of AgNP exposure. In the present paper, we discuss the absorption, toxicodynamics, and metabolism of both Ag and AgNPs in mammals and their health effects.
\end{abstract}

Key words: silver（銀）, nanoparticles（ナノ粒子), argyria（銀皮症）, argyrosis (結膜銀症), methallothionein (メタロチオネイン),

HPLC-ICP-MS（高速液体クロマトグラフィー-誘導結合プラズマ質量分析装置）

\section{1.はじめに}

銀と人類との係わりは紀元前 3000 年前に遡るが, 現在 に至るまで，装飾品・食器などの極めて身近なッールと

受付 2012 年 4 月 13 日, 受理 2012 年 4 月 19 日

Reprint requests to: Takamitsu MIYAYAMA

National Institute for Environmental Studies, 16-2 Onogawa,

Tsukuba, Ibaraki 305-8506, Japan

TEL \& FAX: +81(29)850-2893

E-mail: miyayama.takamitsu@nies.go.jp
して利用されてきているほか，電気および熱伝導率また 可視光線の反射率特性を利用したパソコンの半導体やテ レビ，携帯電話の液晶画面の素材など，銀の用途は多岐 に渡る。その一方で, 近年多用されている銀ナノ粒子は, 健康リスクが懸念される材料としても国際的に注目を浴 びるようになった。実際に産業で用いられている銀が, 環境中にどのよらな化学形態および形状で放出され，あ るいは存在し, ヒトの健康に影響を与えているのかにつ いては不明な点が多い。ここでは，これまでの銀や銀ナ ノ粒子に関する毒性学的知見を紹介しながら，筆者らが 
行っている銀イオンと銀ナノ粒子を曝露した細胞におけ る研究を紹介する。

\section{2. ナノリスクが懸念される材料としての銀の規制}

ナノマテリアルは我々の生活に大きな利益をもたらす ことが期待されているが，環境リスクといら観点からは 不明の点が多く, 近年各国で使用の規制をする動きが出 ている。米国では 2000 年に国家ナノテクノロジ一戦略 (NNI: National Nanotechnology Initiative) が打ち出された が, ナノテクノロジーの環境・健康・安全性についての 課題も指摘されている。その後, 英国, ドイッ等の欧州 でリスクの評価・管理についての指針が出された。2004 年には，英国の王立協会と王立アカデミーが，ナノテク ノロジーは利益をもたらす一方で，リスクに対する責任 ある開発が必要であるといった内容の報告書を公開し た。2006 年には米国・環境保護庁（EPA: United States Environmental Protection Agency）が予測できない環境り スクを及ぼすかもしれないという理由から，ナノ銀を使 用した広範な製品を規制する必要があることを決定し， ワシントンポスト紙がこれを大々的に報道した。このよ らな流れのなかで，経済開発協力機構 (OECD: Organisation for Economic Co-operation and Development）では 2006 年に工業材料としてのナノマテリアルに関する作業部会 （WPMN: Working Party on Manufactured Nanomaterials）を 設置し，銀ナノ粒子も含めたナノマテリアルに関する有 害性の情報や評価手法の検討など，国際的に協調した取 り組みが行われてきている。

\section{3. 抗菌性を利用した銀の利用}

1893 年, スイスの植物学者 Von Nageli は, 当時では分 析できないほどのわずかな量の銀イオンが溶け出した液

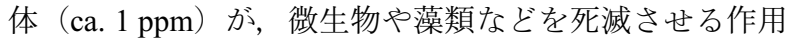
があることを見いだし，この働きを oligodynamic action と 命名した（1）。この現象は，いまでは「微量金属作用」と 呼ばれているが，人や動物が中毒症状を起こすのと同様 に, 細菌や微生物に颃いても許容量を超えて蓄積した金 属イオンがさまざまな酵素を阻害する結果, 細胞の生死 に影響を与えることにより起こる。銀は，細菌，真菌， 原虫の細胞膜表面に存在しているタンパク質に結合し, 貪飲作用 (pinocytosis) によって細胞内一吸収され, DNase やRNaseなどの必須酵素や機能性タンパク質の変性, 不 活化を起こすと考えられている $(2,3)$ 。このよらな antimicrobial action を期待して，これまでに様々な医薬品が 治療目的で利用されている。 silver nitrate や silver sulphadiazine (SSD), 合剂である SSD/chlorhexidine, SSD with cerium nitrate, SSD impregnated lipidocolloid wound dressing, nanocrystalline silverなど多数の医薬品が，主にやけどや 創傷部位の治療に用いられている(3-6)。1999年, Wright らは, silver nitrate, SSD, nanocrystalline silverの各薬剤
をそれぞれ塗布した創傷被膜上での抗菌性を調べ, nanocrystaline silver が最も抗菌効果が高いといら結果を 報告している（7）。2003 年に, Burrell が，60 ppm の銀イ オン溶液であれば，洰とんどの細菌や真菌を制御でき ると報告していることや，同じ報告の中で，院内感染 (nosocomial infection) や日和見感染 (opportunistic infection) の原因菌として注目されている緑膿菌 “Pseudomonas aeruginosa”に対しても，これら銀製剂が極めて有効であ るといら理由から，銀は抗生物質に並ぶ有用性の高い治 療薬と考えられている $(8)$ 。最近では，医薬品への応 用のみならず，銀の殺菌効果が注目され，院内感染の 原因となるメチシリン耐性黄色ブドウ球菌（MRSA: Methicillin-Resistant Staphylococcus Aureus）や多剂耐性緑 膿菌 (MDRP: Multidrug-Resistant Pseudomonas Aeruginosa) を死滅させるものとして，医療施設でも銀素材が積極的 に導入されている。

\section{4. メタロチオネインとその分析手法}

メタロチオネイン（MT）は，分子量 $6,000 \sim 7,000$ ダル トンの低分子タンパク質であり, 哺乳動物では 60 前後の アミノ酸残基により構成されている。4 種類のアイソ フォームの存在が知られており，MT-I及びMT-II は，哺 乳類の組織中に普遍的に存在する一方で，MT-III は神経 細胞，MT-IVは舌といらょうに，組織特異的な発現を示 す。MTの構成アミノ酸の $30 \%$ は，システイン残基から 構成されており，必須元素である亜鉛や銅と結合し，こ れらの必須金属元素のホメオスタシスに関与していると 考えられている。また，MT は有害金属であるカドミウ ム，水銀，銀，鉛にも親和性を持つことから，生体防御 因子としての役割も併せ持つ。MT と金属に打ける親和 性は, $\mathrm{Zn}(\mathrm{II})<\mathrm{Pb}(\mathrm{II})<\mathrm{Cd}(\mathrm{II})<\mathrm{Cu}(\mathrm{I}), \mathrm{Ag}(\mathrm{I}), \mathrm{Hg}(\mathrm{II})$ の順で あることが明らかにされている $(9,10)$ 。MT の定量方法 として，ウエスタンブロッティングやELISAなどのタン パク質量としてアッセイする方法が報告されているが （11），金属毒性と MT の発現量を関連づけて評価する際 には, タンパク質としての MT の発現量を調べることは もちろん, MT にどのような種類の金属がどのくらい分 布しているのかを把握することが重要となる。そのため には，既存の高速液体クロマトグラフィー（HPLC: High Performance Liquid Chromatography）に，誘導結合プラズ マ質量分析装置(ICP-MS: Inductively Coupled Plasma Mass Spectrometry）を組み合わせた HPLC-ICP-MS による解析 手法が有効である。この方法を用いれば，HPLCにより MT などのタンパク質を分離するとともに，タンパク質 に結合した多元素を同時に，かつ高感度分析することが 可能である。銅や亜鉛を結合した MT の生物学的意義や それらの毒性研究の解析に拈いて多数の研究報告がある ことからも (12-15), 今後の金属扎よび金属ナノ材料の 生体内挙動の解析において有用な分析ッールの一つとし て注目される。 


\section{5. 銀イオンの生体影響}

銀は，細胞増殖抑制や DNA 合成抑制（16），マクロ ファージの形態变化や生存の減少 (17), 脂質過酸化の上 昇やチオール化合物の減少（18）など, 様々な生体影響を 及ぼすことが，これまでに報告されている。また，ヒト への慢性曝露により, 銀皮症 (argyria) や結膜銀症 (conjunctival argyrosis) など, 皮膚や眼に抏いて不可逆 的な色素沈着を起こすということが報告されている $(19,20)$ 。しかしながら，既に in vitro 及び in vivo の毒性 研究が多数報告されているにも関わらず，銀の毒性発現 機構については必ずしも明らかにされていない。近年, 銀イオンや銀ナノ粒子が，生活用品として多く利用され ていることから，銀イオンと銀ナノ粒子の毒性を比較し 生体への作用の違いを調べることは重要である。

Dempsey らは銀溶液を飲み水として与えたマウス, ラット，豚における臓器中の銀を，電子顕微鏡を用いて 調べた。その結果, 腎臓, 肝蔵, 甲状腺そして膵臓の各 組織に打いて，銀の顆粒状沈着を確認している(21)。こ の銀の沈着は, argyria と呼ばれているが, 皮膚への不可 逆的な沈着のみならず，組織や器官などへの沈着を含め て広くこの名称が使われている。この症状は，ヒトに拈 いても経口, 吸入, 皮膚接触の 3 つの曝露形態を通して 引き起こされる症状である（Fig. 1)。

経口曝露としては，主に歯科治療で用いられるアマル ガムからの銀溶出や，殺菌を目的とした銀フィルターに よる処理を施した濾過飲料水を摂取するといら経路が考 えられている。アマルガムによる銀溶出の結果, 軟部組 織や血中, 髪の毛, 尿中に扣いて銀の存在が確認されて いる $(22,23)$ 。天然水に含まれる銀の濃度は $0.2 \mu \mathrm{g} / \mathrm{L} て ゙$ あるが，これを銀性のフィルターを介して処理すると， 飲料水中に含まれる銀濃度は $50 \mu \mathrm{g} / \mathrm{L}$ になるという報告 もある。しかし，皃とんどの銀は不溶性の塩化銀として 存在すると考兄られ上に, 仮に銀イオンとして銀フィ ルターにより得られた飲料水を 100 年間飲久続けても七 トへの健康影響に問題はないと考えられている(24)。

コロイド銀の製法過程や銀, 酸化銀, 硝酸銀など産業 被曝による吸入曝露によっても, argyria や argyrosis が拈 こることが知られている $(25,26)$ 。吸入曝露した銀や銀 化合物は, ムコイドや肺胞界面活性物質に結合し肺胞上 皮を通して吸収される。肺に沈着した銀は，肺胞マクロ ファージによって吸収されるといら説 (27) と, 肺胞マク ロファージが吸収を阻害するバリアーとしての機能を持 つといら説がありこの点については明白でない(24)。

銀含有化合物の多くは，ヒトの皮膚表面に打ける抗菌 作用を目的として，やけどや創傷治療薬として用いら れる。皮膚表面に存在するケラチンやリン脂質は, 皮 膚からの銀流入に対するバリアーとして働くことから $(28,29)$, argyria や argyrosis は, 主として吸入や経口に よって引き起こされると考えられるが，銀のヒトへの健 康影響を考える際の曝露ルートとしては, 吸入曝露が最

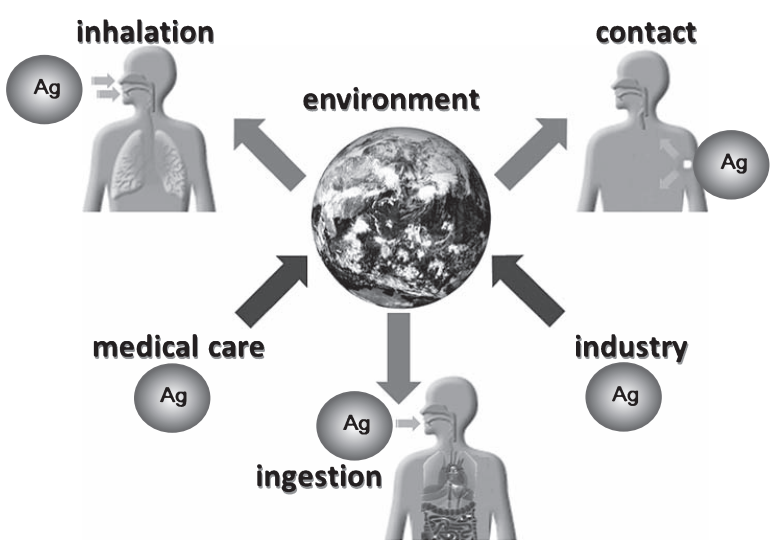

Fig. 1 Exposure route of silver in the environment. Silver is an efficient chemotherapeutic antibacterial and antifungal agent. However, exposure to silver is a potential health risk depending on the amount of absorption of biologically active Ag.

も重要であるといえる。銀曝露によりヒトに健康被害が 及ばないようにするため，政府機関によってヒトへの銀 制限量が提示されている。米国労動安全衛生局（OSHA: Occupational Safety and Health Administration）と米国鉱山 安全衛生局 (MSHA: Mine Safety and Health Administration) は銀及び水溶性銀化合物の許容曝露限界値 (PEL: Permissible Exposure Limit）を $0.01 \mathrm{mg} / \mathrm{m}^{3}$ と設定している一方 で，米国産業衛生専門家会議（ACGIH: American Conference of Governmental Industrial Hygienists）は，職業上の許 容濃度の勧告值（TLV: Threshold Limit Value）として, $0.1 \mathrm{mg} / \mathrm{m}^{3}$ を設定している。各機関によって採用している 数值は異なるが，我が国に抢いては，現在のところ，職 業上の許容曝露濃度として, $0.01 \mathrm{mg} / \mathrm{m}^{3}$ といら数值をす べての銀化合物に扔いて採用している(30)。

生体に取り込まれたのちの銀の毒性機構は不明な点が 多い。in vitro 研究において, 培養細胞に銀を曝露すると, 濃度依存的に細胞毒性が増大寸ることが知られており, その細胞毒性を引き起こす一因として活性酸素の産生が 考えられている(31)。活性酸素を産生する部位について は様々な報告がある（32）。銀は細胞内に取り込まれたの ち，核，ミトコンドリア，リソソームなどの細胞内オル ガネラに蓄積し，毒性を引き起こすことが報告されてい る(33-35)。しかしながら，銀曝露による核， ミトコン ドリア,リソソームなどオルガネラへの影響と, アポトー シスやネクローシスといった細胞死のイベントとの間に は, いくつもの過程が存在するものと考㝋られるが(3639), その最初の段階である具体的な銀の取り込及機構に ついての研究報告は少ない。細胞内の金属の分布や金属 結合タンパク質の挙動や局在を詳細に解析する必要があ り， on-target 型の銀特異的な蛍光プローブなどを用いた 新しい元素イメージング手法の開発が期待される。すで に，他の金属種に打いては，数々の金属特異的なプロー ブの開発がなされており，実際にそのプローブを用いた 研究例も報告されている(40)。 


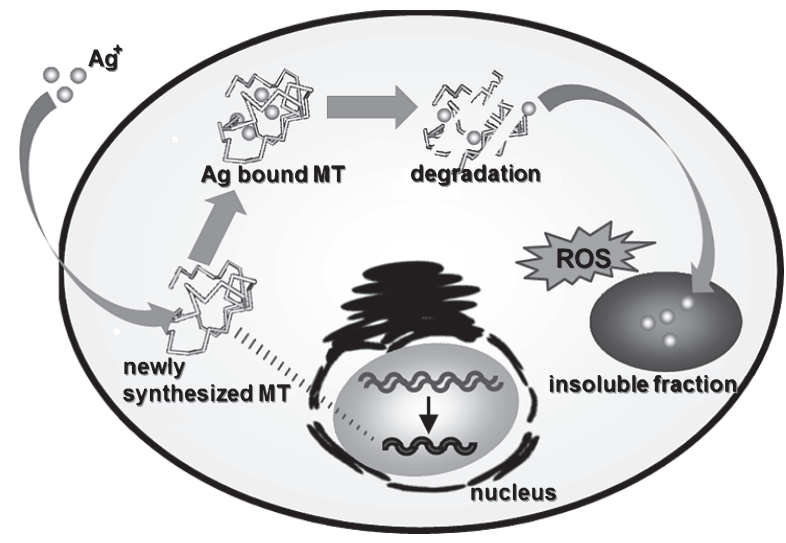

Fig. 2 Accumulation and behavior of silver in human bronchial epithelial cells (BEAS-2B). Newly synthesized MTs inhibit the generation of ROS by exposure to Ag and then ROS level is increased with degradation of Ag-MT and relocalization of $\mathrm{Ag}$ from soluble to insoluble fraction including organelles.

筆者らは, ヒト気道上皮細胞である BEAS-2B 細胞に $\mathrm{AgNO}_{3}$ を曝露した際の $\mathrm{MT}$ の発現と, 細胞内の銀分布に 着目して研究を行っている。これまで, やけどの治療目 的で銀を塗布した際の創傷部位に打ける MT の発現が報 告されているが $(41,42), \mathrm{MT}$ そのものの役割を決定的に 結論づけた報告はない。筆者らの成果から, 細胞内の銀 は，曝露後 3 時間までに可溶性画分中に分布し，以後は 不溶性画分中へ移行することが明らかとなっている。こ のとき, MT の mRNA 量も同様の発現パターンを示して いた。また, 細胞内の $\mathrm{H}_{2} \mathrm{O}_{2}$ 量が, 24 時間後において明 らかに増加していることも認められている。これらの結 果から, 細胞内に取込まれた銀が, 早期の段階でメタ口 チオネインによって捕捉されるが, 銀メタロチオネイン は不安定であるため, 銀は細胞内オルガネラなどが存在 する不溶性画分に移行し, 活性酸素の産生を通して毒性 を沶よぼすものと考えられる（Fig. 2)。

\section{6. ナノマテリアルとしての銀の生体影響}

ナノマテリアルは 21 世紀に入り, 科学技術の進歩とと もに多くの製品に使用されるよらになってきた。2008年 の時点で，現在上市しているナノ含有製品は少なくとも 600 品目を超光, 現在でも週に $3 \sim 4$ 品目が新たに作られ ている。多くのナノ含有製品のらち, 銀含有 74 製品の割 合は最大で，20\%を超える約 140 品目があるとされてい る。その多くはデオドラントスプレー，消臭作用を詔っ た衣料品, 抗菌性を目的とした医療器具, 殺菌・殺虫を 目的とした洗濯機や農薬である。

これまでに報告されている銀ナノ粒子の有害性情報は 多岐に渡るが，ここでは生殖・発生毒性，神経毒性，肺 毒性，遺伝毒性の 4 項目について紹介する。

生殖・発生毒性について, 2005 年, 銀ナノ粒子の毒性 を in vitro 試験にて示唆した報告がなされた。この中で,
Braydich-Stolle らは, マウス生殖細胞に $5 \mu \mathrm{g} / \mathrm{ml}$ 以上の銀 ナノ粒子を曝露させた結果, ミトコンドリア機能の低下, 細胞生存率の減少，細胞毒性マーカーの指標エンザイム である乳酸脱水素酵素（LDH）の漏出が起きることを報 告している $(43) 。 2010$ 年, $\mathrm{Li}$ らは，マウス桑実胚と胚盤 胞を用いて，銀ナノ粒子と銀イオンを曝露した際の影響 を調べた。その結果，in vitro 試験での胚発育は，銀ナ， 粒子の曝露により, 着床後の発育率低下が示されたほか, in vivo 試験でも，着床率が有意に減少し，胎盤や胎仔の 重量は対照より減少することが分かった。また，この現 象の背景に，銀ナノ粒子が，マウス胚盤胞にアポトーシ スを誘導することや, 内部細胞塊と栄養外肧葉の細胞増 殖を抑制しアポトーシスを誘導すると考えられている。 すなわち，銀ナノ粒子は，着床後の胚の発育に拈ける胚 盤胞や着床にも影響を示すことが示された (44)。

神経毒性について，2009 年 Tang らは，ラットに銀ナ

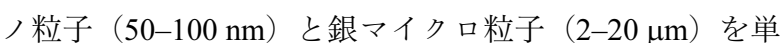
回皮下投与し，2〜24 週間後の各組織を調べた。その結 果，銀ナノ粒子は血液循環を介して，腎蔵，肝臓，脾臓， 脳，肺に分布することが分かった。さらに，血液脳関門 の破壊やアストロサイトの膨化を誘導し, ニューロン変 性を引き起こすことが明らかとなった。な执，銀マイク 口粒子は血流及び蔵器組織に侵入していなかったことか ら，銀ナノ粒子の生物医学的アプリケーション，特に長 期間使用の際には，標的藏器の機能評価や神経毒性に注 意する必要性が示された (45)。

肺毒性については，2009 年 Sung らは，49 $\mu \mathrm{g} / \mathrm{m}^{3} \quad(0.6$ $\times 10^{6}$ 個 $\left./ \mathrm{cm}^{3}\right), 133 \mu \mathrm{g} / \mathrm{m}^{3}\left(1.4 \times 10^{6}\right.$ 個 $\left./ \mathrm{cm}^{3}\right), 515 \mu \mathrm{g} / \mathrm{m}^{3}$ $\left(3.0 \times 10^{6}\right.$ 個 $\left./ \mathrm{cm}^{3}\right)$ の濃度の銀ナノ粒子を，ラットに 1 日 6 時間, 週 5 日間で 90 日間, OECD413 ガイドラインに基 づき全身吸入曝露を行った結果を報告している。その結 果, 銀ナノ粒子曝露群はコントロール群（新鮮な空気に 曝露）と比較して, 雌雄ラットの肝藏に扔いて用量に応 じた胆管の過形成が見られ，肺に执いても銀の用量に応 じた血管周囲の炎症性細胞浸潤, 肺胞の慢性炎症, 肉芽 腫性病変, 肺胞マクロファージの滞留が観察された。臓 器中の銀濃度は, 高用量で雌雄ラット共に肺, 肝臓, 脳, 嗅球, 腎臓において蓄積が見られ, 中用量では, 雄の肺, 腎臓, 脳, 雌の肺, 脳において蓄積が見られた。特に腎 蔵においては, 雌が雄に比べて 2-3 倍増加しており, 性 差がみられた。これらの結果を経口投与における臓器中 の銀の蓄積データと比較すると, 経口投与の場合に肺は 主たる分布臓器ではないと考えられた。また, トロンボ プラスチンとプロトロンビン時間を指標とした赤血球凝 集検査と尿中 N-アセチル $\beta$ - D-グルコサミニダーゼを指 標とした腎機能検査に掞いて，高用量の雌においてコン トロールに比較して, 赤血球凝集の有意な变化が見られ, 高用量の雄に括いては尿中蛋白の有意な上昇が見られて いることから，吸入曝露による銀ナノ粒子の標的蔵器は 雌雄共に，主として肺，肝臓であり，ラット雌雄に抢け る肝臓胆管の過形成, 肺胞の慢性炎症, 肺胞マクロファー 


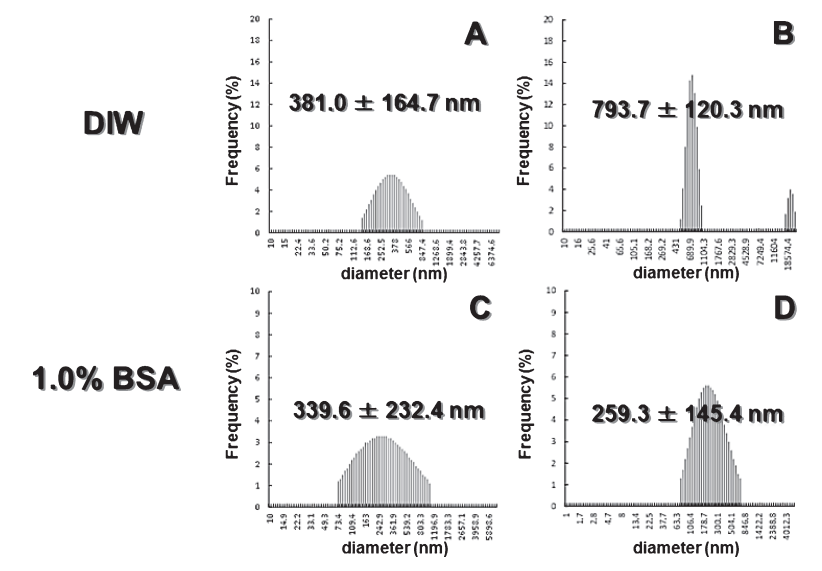

Fig. 3 Differential scattered light intensities of AgNPs $(<\mathbf{1 0 0} \mathbf{~ n m})$. The size distribution of AgNPs was measured by DLS just after re-suspension in deionized water (A), after $30 \mathrm{~min}$ of incubation at $25^{\circ} \mathrm{C}(\mathrm{B})$, and after $30 \mathrm{~min}$ incubation in culture medium containing $1 \%$ bovine serum albumin at $25^{\circ} \mathrm{C}(\mathrm{C})$.

ジの滞留, 雌における赤血球凝集を考慮して, NOAEL は $100 \mu \mathrm{g} / \mathrm{m}^{3}$ と報告されている (46)。

遺伝毒性については, 2009 年 Kim らは, ヒト hepatoma HepG2 細胞に, 0-10 $\mu \mathrm{g} / \mathrm{mL}$ の銀ナノ粒子を処理した実験 結果を報告している。その結果, 銀ナノ粒子及び銀イオ ンは，濃度依存的に細胞中で細胞質と核に凝集し，細胞 内酸化ストレスを誘導しDNA を損傷させた。また，こ の DNA 損傷は，抗酸化剂である N-アセチルシステイン で阻止された。つまり，銀ナノ粒子の DNA 損傷は主に 酸化ストレスの結果おこることが推測された。本実験に 供した銀ナノ粒子は銀イオンの含有を無視できるものと していることから, 銀ナノ粒子の毒性は銀イオンには依 存していないと報告している(35)。

以後, 銀ナノ粒子の毒性として，血液脳関門に炎症を 引き起こして透過性を上昇させる可能性や (47), 細胞周 期を G2/M 期で停止させる作用 (48) などの遺伝毒性が報 告されていることから (49-51)，アポトーシスの起因や がん進展への影響を調べた研究が, 多数報告されている。

筆者らは, マウスマクロファージ細胞株である J774.1 細 胞を用いて, 銀ナノ粒子の細胞内取り込久の評価を行っ ている。ここでは, 銀ナノ粒子の毒性研究を始めるに当 たり，これまでも論文等で報告されているナノ材料の凝 集性の問題を回避するため (31), その曝露方法を検討し た。また，検討した曝露方法を用いて，銀ナノ粒子の細胞 内取り込み量と細胞毒性について検討した。ここでは, 再 分散性を検討する実験として, 脱イオン水と終濃度にして 1\% ウシ血清アルブミン（BSA; Bovine Serum Albumin）を 含む培養液に分散させたときの銀ナノ粒子の分散性を動 的光散乱光度計（DLS: Dynamic Light Scattering）を用い て継時的に観察した。30分後において，脱イオン水で懸 濁した銀ナノ粒子は凝集を起こしたが，1\% BSA 細胞培 養液中の銀ナノ粒子は凝集を起こさなかった (Fig. 3)。20, $60,100 \mathrm{~nm}$ の各サイズの銀ナノ粒子を，再分散溶媒とし

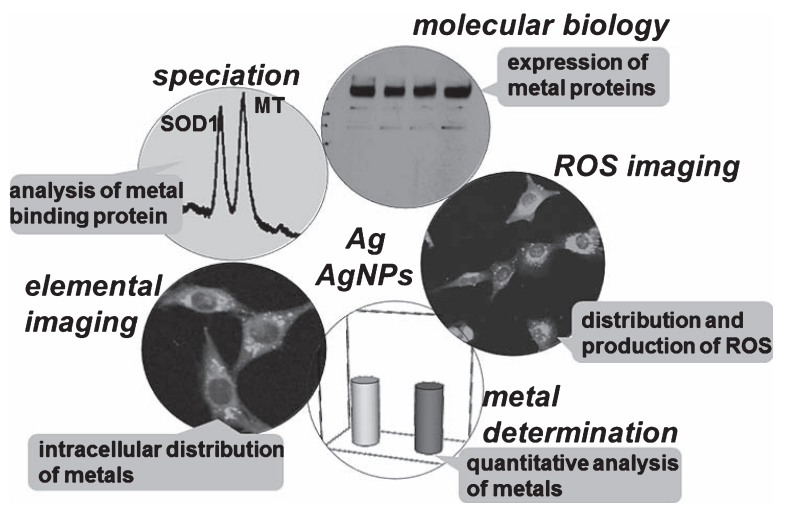

Fig. 4 The multi-dimensional approach for the study of silver toxicity. This approach consists of metal analysis, bio-imaging and molecular biological techniques. HPLC-ICP-MS is used to determine the chemical species of $\mathrm{Ag}$, a fluorescent probe, CM- $\mathrm{H}_{2}$ DCFDA, is used for bio-imaging of ROS. Some molecular biological techniques are applicable to elucidate cellular responses such as transcriptional induction, gene product expression, and localization of target proteins in mammalian cells.

て 10\%アルブミン溶液に懸濁し, 細胞培養液で希釈した ところ，10.7 $\pm 0.8,74.8 \pm 18.3,118.7 \pm 29.0 \mathrm{~nm}$ であり，そ れ亖の銀ナノ粒子の一次粒径がほぼ保たれているとい ら結果を得ている。さらに，この曝露条件を用いて， $\mathrm{J} 774.1$ 細胞に終濃度で 0 から $100 \mu \mathrm{g} \mathrm{Ag} / \mathrm{mL}$ の銀ナノ粒子 および $\mathrm{AgNO}_{3}$ を曝露し細胞毒性を評価したところ, 24 時 間後では, $100 \mu \mathrm{g} \mathrm{Ag} / \mathrm{mL}$ の濃度で, $100 \mathrm{~nm}, 60 \mathrm{~nm}$ の銀ナ ノ粒子で $29 \%, 20 \mathrm{~nm}$ の銀ナノ粒子で $47 \%$ の細胞が死滅 し, $\mathrm{AgNO}_{3}$ に打いては $74 \%$ が死滅した。細胞内への銀ナ ノ粒子取り込又を銀含有量として評価するため, ICP-MS を用いて培地扣よび細胞上清の ${ }^{107} \mathrm{Ag}$ を定量した結果か ら，銀ナノ粒子の取り込みは，30 分以内に取り込みが始 まり，6時間後には最大值に達している様子が観察され た。以上の事から，アルブミンを用いることで，培地塩 濃度での銀ナノ粒子の凝集性を回避できることがわかっ た。さらに，銀ナノ粒子は粒径が小さい注ど毒性が強い ことが明らかとなった。

\section{7.おわりに}

これまで報告されてきた銀の毒性やリスク評価に関す る研究報告に抢いては，銀イオン，マイクロサイズの銀 粒子，あるいは銀ナノ粒子が用いられているが，銀粒子 の溶解性や表面に打ける生体分子との相互作用なども含 めて包括的に研究された例は少ない。これからの金属・ 金属ナノ材料の毒性評価は, 物質の物理化学的性状を考 慮しつつ, タンパク質の発現や転写解析, 防御因子の細 胞内局在などの分子生物学的手法や活性酸素に代表され る毒性マーカーのイメージング手法に加えて，曝露する 対象をより正確に追跡できるような分析手法の開発や応 用が必要であると考えられる（Fig. 4)。金属結合タンパ ク質の定量解析に拈いては, 分離定量解析を可能とさせ 
る HPLC-ICP-MS の導入や，銀ナノ粒子そのものに蛍光 物質を施した蛍光ナノ粒子など，今後の銀ナノ粒子の毒 性及びリスクの評価にこれらの新規分析手法が，新しい ナノ材料の分析手法として評価法の礎になることを期待 したい。

\section{文献}

(1) Nageli KV. On the oligodynamic phenomenon in living cells. Denkschriften der Schweizerischen Naturforschenden Gesellschaft. 1893;33:174-182.

(2) Landsdown AB, Williams A. Bacterial resistance to silver in wound care and medical devices. J Wound Care. 2007; 16:15-19.

(3) Russell AD, Hugo WB. Antimicrobial activity and action of silver. Prog Med Chem. 1994;31:351-370.

( 4 ) Carsin H, Wassermann D, Pannier M, Dumas R, Bohbot S. A silver sulphadiazine-impregnated lipidocolloid wound dressing to treat second-degree burns. J Wound Care. 2004; 13:145-148.

( 5 ) Carneiro PM, Rwanyuma LR, Mkony CA. A comparison of topical Phenytoin with Silverex in the treatment of superficial dermal burn wounds. Cent Afr J Med. 2002;48:105108.

( 6 ) Monafo WW, Freedman B. Topical therapy for burns. Surg Clin North Am. 1987;67:133-145.

( 7 ) Wright JB, Lam K, Hansen D, Burrell RE. Efficacy of topical silver against fungal burn wound pathogens. Am J Infect Control. 1999;27:344-350.

( 8 ) Burrell RE. A scientific perspective on the use of topical silver preparations. Ostomy Wound Manage. 2003;49:19-24.

(9) Kabzinski AK. The determination of environmental and industrial exposure to heavy metals based on the quantitative isolation of metallothionein from human fluids, with application of covalent affinity chromatography with thioldisulphide interchange gel as a solid-phase extraction support. Talanta. 1998;46:335-346.

(10) Kagi JH, Kojima Y. Chemistry and biochemistry of metallothionein. Experientia Suppl. 1987;52:25-61.

(11) Chan HM, Cherian MG, Bremner I. Quantification of metallothionein isoforms using an enzyme-linked immunosorbent assay (ELISA) with two specific antisera. Toxicol Appl Pharmacol. 1992;116:267-270.

(12) Miyayama T, Ishizuka Y, Iijima T, Hiraoka D, Ogra Y. Roles of copper chaperone for superoxide dismutase 1 and metallothionein in copper homeostasis. Metallomics. 2011; 3:693-701.

(13) Miyayama T, Hiraoka D, Kawaji F, Nakamura E, Suzuki N, Ogra Y. Roles of COMM-domain-containing 1 in stability and recruitment of the copper-transporting ATPase in a mouse hepatoma cell line. Biochem J. 2010;429:53-61.

(14) Miyayama T, Suzuki KT, Ogra Y. Copper accumulation and compartmentalization in mouse fibroblast lacking metallothionein and copper chaperone, Atox1. Toxicol Appl Pharmacol. 2009;237:205-213.

(15) Miyayama T, Ogra Y, Osima Y, Suzuki KT. Narrow-bore
HPLC-ICP-MS for speciation of copper in mutant mouse neonates bearing a defect in $\mathrm{Cu}$ metabolism. Anal Bioanal Chem. 2008;390:1799-1803.

(16) Hidalgo E, Domínguez C. Study of cytotoxicity mechanisms of silver nitrate in human dermal fibroblasts. Toxicol Lett. 1998;98:169-179.

(17) Rungby J, Hultman P, Ellermann-Erikson S. Silver affects viability and structure of cultured mouse peritoneal macrophages and peroxidative capacity of whole mouse liver. Arch Toxicol. 1987;59:408-412.

(18) Baldi C, Minoia C, Di Nucci A, Capodaglio E, Manzo L. Effects of silver in isolated rat hepatocytes. Toxicol Lett. 1988;41:261-268.

(19) Atiyeh BS, Costagliola M, Hayek SN, Dibo SA. Effect of silver on burn wound infection control and healing: Review of the literature. Burns. 2007;33:139-148.

(20) Lansdown AB. Silver in health care: antimicrobial effects and safety in use. Curr Probl Dermatol. 2006;33:17-34.

(21) Dempsey EW, Wislocki GB. The use of silver nitrate as a vital stain, and its distribution in several mammalian tissues as studied with the electron microscope. J Biophys Biochem Cytol. 1955;1:111-118.

(22) Drasch G, Gath HJ, Heissler E, Schupp I, Roider G. Silver concentrations in human tissues. their dependence on dental amalgam and other factors. J Trace Elem Med Biol. 1995;9: $82-87$.

(23) Viala A, Gilles G, Sauve JM, Alibert JP. [Influence of dental amalgams on the concentration of mercury and silver in biological fluids and hair (author's transl)]. Toxicol Eur Res. 1979;2:47-53.

(24) Lansdown AB. A pharmacological and toxicological profile of silver as an antimicrobial agent in medical devices. Adv Pharmacol Sci. 2010;2010:910686.

(25) Fung MC, Weintraub M, Bowen DL. Colloidal silver proteins marketed as health supplements. JAMA. 1995;274: 1196-1197.

(26) Bleehen SS, Gould DJ, Harrington CI, Durrant TE, Slater DN, Underwood JC. Occupational argyria; light and electron microscopic studies and $\mathrm{X}$-ray microanalysis. $\mathrm{Br} \mathrm{J}$ Dermatol. 1981;104:19-26.

(27) Takenaka S, Karg E, Roth C, Schulz H, Ziesenis A, Heinzmann U, Schramel P, Heyder J. Pulmonary and systemic distribution of inhaled ultrafine silver particles in rats. Environ Health Perspect. 2001;109 Suppl 4:547-551.

(28) Lansdown AB. Physiological and toxicological changes in the skin resulting from the action and interaction of metal ions. Crit Rev Toxicol. 1995;25:397-462.

(29) Hostynek JJ, Hinz RS, Lorence CR, Price M, Guy RH. Metals and the skin. Crit Rev Toxicol. 1993;23:171-235.

(30) Drake PL, Hazelwood KJ. Exposure-related health effects of silver and silver compounds: a review. Ann Occup Hyg. 2005;49:575-585.

(31) Foldbjerg R, Olesen P, Hougaard M, Dang DA, Hoffmann HJ, Autrup H. PVP-coated silver nanoparticles and silver ions induce reactive oxygen species, apoptosis and necrosis in THP-1 monocytes. Toxicol Lett. 2009;190:156-162.

(32) Li N, Sioutas C, Cho A, Schmitz D, Misra C, Sempf J, 
Wang M, Oberley T, Froines J, Nel A. Ultrafine particulate pollutants induce oxidative stress and mitochondrial damage. Environ Health Perspect. 2003;111:455-460.

(33) Teodoro JS, Simoes AM, Duarte FV, Rolo AP, Murdoch RC, Hussain SM, Palmeira CM. Assessment of the toxicity of silver nanoparticles in vitro: a mitochondrial perspective. Toxicol In Vitro. 2011;25:664-670.

(34) Greulich C, Diendorf J, Simon T, Eggeler G, Epple M, Köller M. Uptake and intracellular distribution of silver nanoparticles in human mesenchymal stem cells. Acta Biomaterialia. 2011;7:347-354.

(35) Kim S, Choi JE, Choi J, Chung KH, Park K, Yi J, Ryu DY. Oxidative stress-dependent toxicity of silver nanoparticles in human hepatoma cells. Toxicol In Vitro. 2009;23:10761084.

(36) Hussain SM, Hess KL, Gearhart JM, Geiss KT, Schlager JJ. In vitro toxicity of nanoparticles in BRL 3A rat liver cells. Toxicol In Vitro. 2005;19:975-983.

(37) Upadhyay D, Panduri V, Ghio A, Kamp DW. Particulate matter induces alveolar epithelial cell DNA damage and apoptosis: role of free radicals and the mitochondria. Am J Respir Cell Mol Biol. 2003;29:180-187.

(38) Hiura TS, Li N, Kaplan R, Horwitz M, Seagrave JC, Nel AE. The role of a mitochondrial pathway in the induction of apoptosis by chemicals extracted from diesel exhaust particles. J Immunol. 2000;165:2703-2711.

(39) Hiura TS, Kaszubowski MP, Li N, Nel AE. Chemicals in diesel exhaust particles generate reactive oxygen radicals and induce apoptosis in macrophages. J Immunol. 1999; 163:5582-5591.

(40) Domaille DW, Que EL, Chang CJ. Synthetic fluorescent sensors for studying the cell biology of metals. Nat Chem Biol. 2008;4:168-175.

(41) Lansdown AB. Metallothioneins: potential therapeutic aids for wound healing in the skin. Wound Repair Regen. 2002; 10:130-132.

(42) Lansdown AB, Sampson B, Laupattarakasem P,
Vuttivirojana A. Silver aids healing in the sterile skin wound: experimental studies in the laboratory rat. $\mathrm{Br} \mathrm{J}$ Dermatol. 1997;137:728-735.

(43) Braydich-Stolle L, Hussain S, Schlager JJ, Hofmann MC. In vitro cytotoxicity of nanoparticles in mammalian germline stem cells. Toxicol Sci. 2005;88:412-419.

(44) Li PW, Kuo TH, Chang JH, Yeh JM, Chan WH. Induction of cytotoxicity and apoptosis in mouse blastocysts by silver nanoparticles. Toxicol Lett. 2010;197:82-87.

(45) Tang J, Xiong L, Wang S, Wang J, Liu L, Li J, Yuan F, Xi T. Distribution, translocation and accumulation of silver nanoparticles in rats. J Nanosci Nanotechnol. 2009;9:49244932.

(46) Sung JH, Ji JH, Park JD, Yoon JU, Kim DS, Jeon KS, Song MY, Jeong J, Han BS, Han JH, Chung YH, Chang HK, Lee JH, Cho MH, Kelman BJ, Yu IJ. Subchronic inhalation toxicity of silver nanoparticles. Toxicol Sci. 2009;108: 452-461.

(47) Trickler WJ, Lantz SM, Murdock RC, Schrand AM, Robinson BL, Newport GD, Schlager JJ, Oldenburg SJ, Paule MG, Slikker W Jr, Hussain SM, Ali SF. Silver nanoparticle induced blood-brain barrier inflammation and increased permeability in primary rat brain microvessel endothelial cells. Toxicol Sci. 2010;118:160-170.

(48) Lee YS, Kim DW, Lee YH, Oh JH, Yoon S, Choi MS, Lee SK, Kim JW, Lee K, Song CW. Silver nanoparticles induce apoptosis and G2/M arrest via PKCzeta-dependent signaling in A549 lung cells. Arch Toxicol. 2011;85:1529-1540.

(49) AshaRani PV, Low Kah Mun G, Hande MP, Valiyaveettil S. Cytotoxicity and genotoxicity of silver nanoparticles in human cells. ACS Nano. 2009;3:279-290.

(50) Asharani PV, Hande MP, Valiyaveettil S. Anti-proliferative activity of silver nanoparticles. BMC Cell Biol. 2009;10:65.

(51) Foldbjerg R, Dang DA, Autrup H. Cytotoxicity and genotoxicity of silver nanoparticles in the human lung cancer cell line, A549. Arch Toxicol. 2011;85:743-750. 